\title{
Bioengineering considerations in liver regenerative medicine
}

\author{
Ogechi Ogoke ${ }^{1,2}$, Janet Oluwole $e^{2,3^{*}}$ and Natesh Parashurama ${ }^{1,2,3^{*}}$ (D)
}

\begin{abstract}
Background: Liver disease contributes significantly to global disease burden and is associated with rising incidence and escalating costs. It is likely that innovative approaches, arising from the emerging field of liver regenerative medicine, will counter these trends.

Main body: Liver regenerative medicine is a rapidly expanding field based on a rich history of basic investigations into the nature of liver structure, physiology, development, regeneration, and function. With a bioengineering perspective, we discuss all major subfields within liver regenerative medicine, focusing on the history, seminal publications, recent progress within these fields, and commercialization efforts. The areas reviewed include fundamental aspects of liver transplantation, liver regeneration, primary hepatocyte cell culture, bioartificial liver, hepatocyte transplantation and liver cell therapies, mouse liver repopulation, adult liver stem cell/progenitor cells, pluripotent stem cells, hepatic microdevices, and decellularized liver grafts.

Conclusion: These studies highlight the creative directions of liver regenerative medicine, the collective efforts of scientists, engineers, and doctors, and the bright outlook for a wide range of approaches and applications which will impact patients with liver disease.

Keywords: Liver transplantation, Liver regeneration, Primary hepatocyte cell culture, Bioartificial liver, Hepatocyte transplantation, Liver cell therapies, Mouse liver repopulation, Liver cell therapies, Adult liver stem cell/progenitor cells, Pluripotent stem cells, Hepatoxicity and engineered devices, Decellularized liver grafts
\end{abstract}

\section{Background}

\section{The increasing global burden of liver disease}

The incidence and prevalence of chronic liver disease (CLD), manifested by the presence of fibrosis/cirrhosis and end stage liver disease, is reaching epidemic proportions worldwide, with 50 million affected. In developed countries, like the US, UK, Spain, and France, CLD rates have risen such that it is a leading cause of death (UK national statistics, https://www.gov.uk/government/statistics). In the US, more than 5 million Americans are living with CLD and by 2020, cirrhosis is projected to be the 12th leading cause of mortality [1]. The increased prevalence of CLD is linked to several factors, including non-alcoholic fatty liver disease

\footnotetext{
* Correspondence: janetolu@buffalo.edu; nateshp@buffalo.edu ${ }^{2}$ Clinical and Translation Research Center (CTRC), University at Buffalo (State University of New York), 875 Ellicott St., Buffalo, NY 14203, USA 'Department of Chemical and Biological Engineering, University at Buffalo (State University of New York), Furnas Hall, Buffalo, NY 14260, USA Full list of author information is available at the end of the article
}

(NAFLD) and associated nonalcoholic steatohepatitis (NASH) [2], Hepatitis B and C [3], and alcoholic hepatitis [4]. Furthermore, hepatocellular carcinoma (HCC), one of the leading causes of death worldwide, is rapidly increasing in incidence, and advanced HCC is treated with liver transplantation, and is thus relevant to liver regenerative medicine [5].

\section{Liver functions and liver mass}

The liver is the largest internal organ and bears the unique ability to regenerate itself, whilst performing central metabolic, detoxification, synthetic, digestive, endocrine, immunoregulatory, and exocrine functions (Fig. 1). The parenchymal cell of the liver, the hepatocyte, is a complex, energetically intensive, polarized epithelial cell. The mass of the liver is central to its function.

The human adult liver weighs approximately $1.4-1.7 \mathrm{~kg}$, with a hepatocyte density of $1.1-1.6 \times 10^{8}$ cells /g [6], and has an estimated number of $2 \times 10^{11}$ or 200 billion hepatocytes. A 7-10 week old Sprague-Dawley adult female 


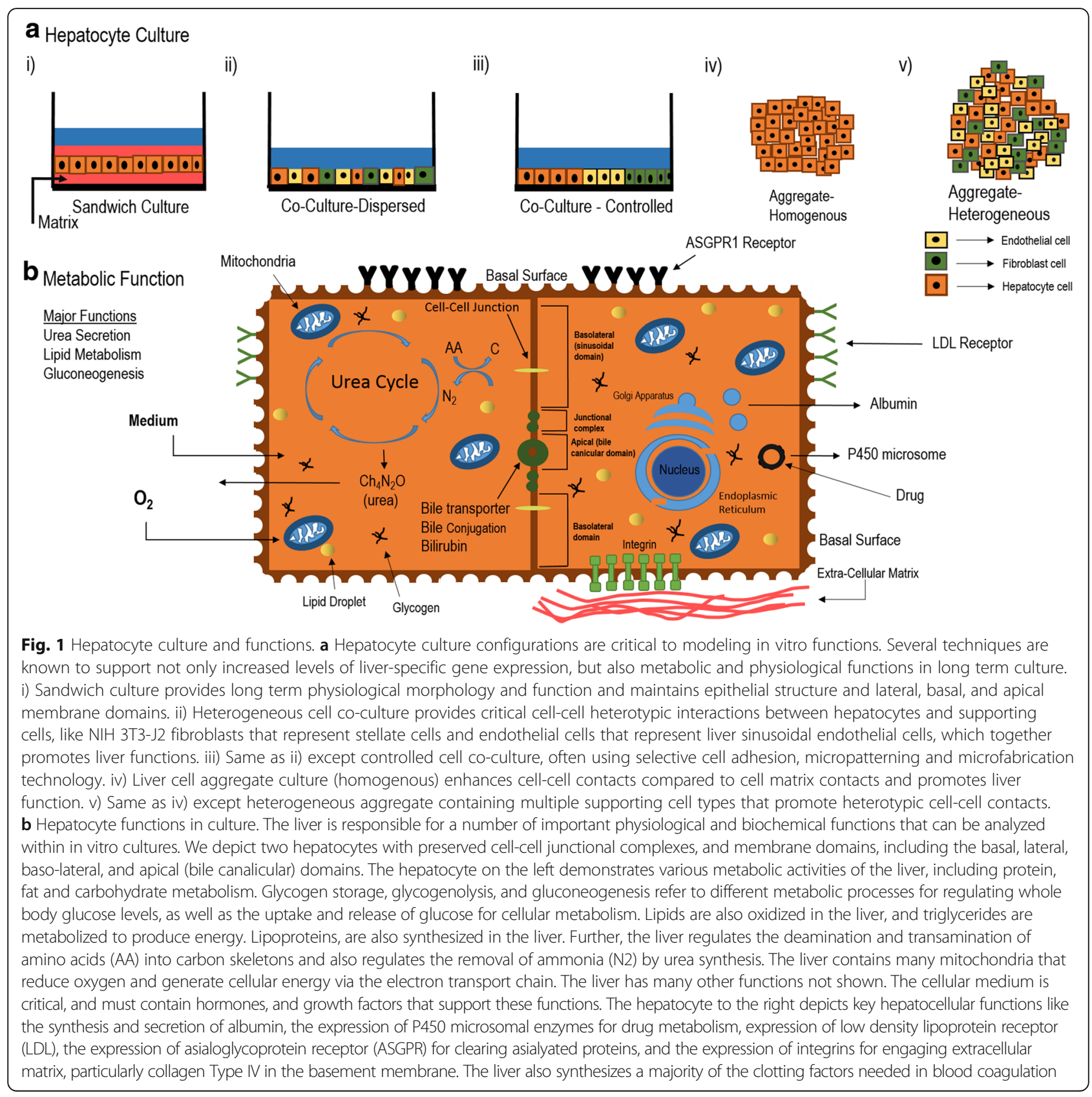

rat, with a weight of 150-200 g and liver weight of about $7.7 \mathrm{~g}$, bears approximately $1 \times 10^{9}$ or 1 billion hepatocytes [6]. An adult 8-10 week old BL6 adult female mouse, with a weight of $16 \mathrm{~g}$ and a liver weight of $1.25 \mathrm{~g}$, bears approximately $1.5 \times 10^{8}$ or 150 million hepatocytes [6]. A key point is that replacing about $10 \%$ of liver function, which is still a large mass of cells, can support liver function in acute disease [7].

\section{Liver transplantation}

Despite the increasing need for liver tissue and a shortage of available donor livers, the current standard of care for end stage liver disease is liver transplantation. Approximately 20,000 orthotopic liver transplants are conducted annually worldwide. In the US, the 1 year survival rate is $85 \%-88 \%$, the 5 -year survival rate is $74 \%$, and 2000 patients die annually waiting for a donor liver [8]. Orthotopic liver transplantation was aggressively investigated following successful transplantation of the bone marrow and the kidney in the mid 1950's [9]. Years of basic and preclinical research led to reduced complications and increased survival rates, such that currently, the most common risk factor resulting in liver failure post-transplantation is poor quality of the donor liver. 
Scarcity of healthy donor livers is being addressed by increasing the donor pool, improving preservation of the graft, and minimizing time of post-harvest survival prior to transplant. Machine perfusion of the donor liver is a promising approach for increasing the donor pool [10]. This approach can function either by reducing complications associated with traditional storage and transplantation, or by metabolic reconditioning livers which are considered marginal. Living donor liver transplantation introduces alternate techniques for harvesting of living liver tissue followed by transplantation, without the need for cryopreservation with subsequent liver ischemia. This approach is particularly relevant for pediatric patients, due to limited donor size for living donors [11]. Collectively, liver transplantation is successful because technical and scientific aspects have been addressed, but the procedures themselves are expensive, and patients require lifelong immunosuppression.

\section{Liver regeneration}

Liver regeneration stemming from the loss of hepatic tissue due to injury is a unique property among the internal organs $[12,13]$. The hepatocyte is the parenchymal cell of the liver, and is mature, quiescent, and expresses a vast array of differentiated genes to support its extensive functions (Fig. 1). In spite of its mature differentiated functions, the hepatocyte cell cycle is activated in response to acute liver injury, such as two thirds hepatectomy. During liver regeneration, synchronized replication of hepatocytes [14], followed by coordinated replication of nonparenchymal cells, leads to rapid and complete replacement of liver mass, function, and microarchitecture. Importantly, during regeneration, hepatocytes express over 1000 genes while sustaining essential liver functions that ensure survival of the organism [13]. Despite this robust regenerative response in acute disease, regeneration is dysfunctional in cirrhosis, and in this case, does not appreciably restore normal hepatic tissue homeostasis, microarchitecture and function.

\section{Early studies in liver regenerative medicine}

The roots of modern liver regenerative medicine began in part with development of an apparatus to study the basic science and biochemistry of isolated perfused rat livers $[15,16]$. Here, the whole liver can be removed from the intact organism, bathed, maintained to improve viability, and perfused under pseudo-physiological conditions. These techniques, together with improved analytical capabilities, helped uncover liver physiology and biochemistry. While these whole organ techniques were extremely informative, further study required isolation of the viable hepatocytes [17, 18]. Availability of hepatocytes furthered mechanistic studies, and provided a cell source for in vivo hepatocyte transplantation studies. However, despite these advances, new challenges were apparent, as isolated hepatocytes were unable to be cultivated in vitro for more than twenty-four hours using traditional seeding on tissue culture-treated plastic.

\section{Development of long term primary hepatocyte culture Hepatocyte culture}

Although isolated hepatocytes were initially the mainstay of basic liver studies, the inability to cultivate hepatocytes long term, with physiological functions, limited potential applications (Fig. 2). Initial investigation of primary hepatocytes, employing cell adhesion to tissue culture plastic, resulted in a flat, rather than cuboidal, morphology, characterized by dedifferentiation. Based on initial findings, scientists developed co-cultivation approaches based upon extracellular matrix composition, with a focus for maintaining liver morphology and functions long term [19-21]. The culture of primary rat hepatocytes in a double gel, or sandwich, configuration, was the first experimental culture system displaying physiological functions for greater than 3 weeks [22]. In these seminal studies, the measurement of albumin production rate was utilized as a metric for liver synthetic function, and measured $\sim 5 \mu \mathrm{g} / \mathrm{h}$ per 2 million plated hepatocytes. Urea, a product of ammonia metabolism related to hepatocyte catabolism of proteins and amino acids, measured $\sim 4 \mu \mathrm{g} / \mathrm{h}$ per 2 million cells after 2 weeks of culture. The analysis of the functionality of liver specific cytochrome P450 (CYP) enzymes, which participate in metabolism of drugs and toxic compounds, showed increased activity. In addition, hepatocytes excrete bile across the apical domain of the cell membrane. Early studies highlighted the detection of bile canaliculi proteins and hepatocyte bile secretions in the double gel culture systems. These seminal studies opened up further areas of in vitro investigation, regarding the hepatocyte's biochemical and metabolic responses to oxygen, lipids, and plasma exposure in the setting of bioartificial design [23-26].

In vitro hepatocellular organization, as a function of microenvironment, has been investigated with careful application of engineering tools and technologies. When cultivated on biomechanically soft surfaces, hepatocytes form three dimensional clusters, or aggregates. Interestingly, these aggregates also lead to stable hepatocyte functions and are an alternate culture configuration $[27,28]$. Studies demonstrate that the advantages of aggregate culture, synonymous with spheroid or organoid culture, include increased cell-cell homotypic interactions, and ease of manipulation of tissue units. The disadvantages of aggregate culture include transport limitations, cellular heterogeneity, and lack of cord like liver microstructure. Thus each culture system 


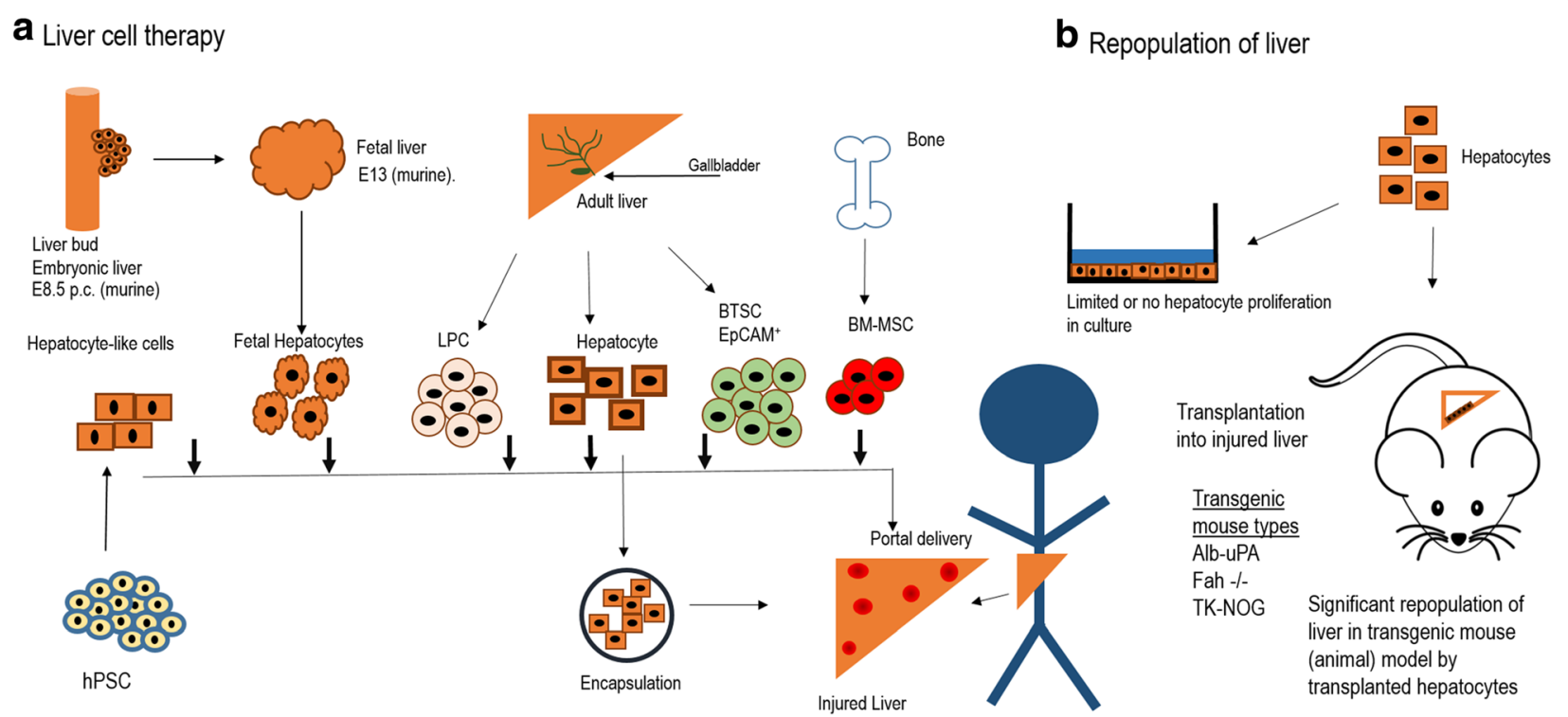

Fig. 2 Liver cell therapy and liver repopulation. a The various types of liver cell therapies. Liver cell therapy utilizes a wide range of cells, from different stages of liver development and different tissue types, to treat acute or chronic liver disease. The liver develops from the liver bud (embryonic liver, E8.5) to form the fetal liver (fetal hepatocytes), neonatal liver, followed by adult liver (hepatocytes, liver progenitor cells, (LPC), biliary tree stem cells (BTSC)). Adult bone marrow (bone marrow-derived mesenchymal cells(BM-MSC), and other bone marrow cells) are also used as a cell source. Human pluripotent stem cells (hPSC) are used for differentiation towards hepatocyte-like cells. In encapsulation, shown below, therapeutic cells are placed within microcapsules to improve cell viability upon transplantation by protecting therapeutic cells. Delivery to the liver is often via the portal vein. $\mathbf{b}$ Liver Repopulation. Liver repopulation is an experimental procedure performed in transgenic mice. Activation of transgene in the liver injures or kills endogenous hepatocytes. Because of the regenerative capacity of the liver, the remaining injured cells would normally replicate within the liver to replace, or repopulate any empty areas. Because the endogenous hepatocytes are injured, they are unable to repopulate the liver. At the same time, if healthy hepatocytes are injected into the spleen, they will outcompete the native hepatocytes and will repopulate the liver. This assay can be used to assess the regenerative function of adult hepatocytes. Furthermore, it can be used to create a chimeric mouse with new hepatocytes, which may carry a disease causing gene and be used for disease modeling. Finally, if the host mice are both transgenic and immunodeficient, the animals can be used to bear human hepatocytes within the mouse liver, to create a human in-liver mouse. This can be used for disease modeling or testing hepatotoxicity or drug metabolism of human hepatocytes in mice. These transgenic animals can be used to expand primary hepatocytes, which typically don't expand in culture

can be chosen based on the question being asked and tailored to the desired application [29].

In parallel with development of culture systems, scientists explored the integration of engineered biomaterials with hepatocyte culture. Investigation into the science behind hepatocyte morphology and function demonstrated that aggregate size, scaffold topography, mechanochemical interactions, and ligand presentation distinctly modulate hepatospecific functions [30-33]. To model multicellular cords in the liver, bioengineers developed multilayering approaches based on thin polyelectrolyte films $[34,35]$ which maintain hepatocellular functions. Collectively, these studies highlighted the complex effects of extracellular matrix on hepatocyte morphology and function, and led to the development of key hepatocyte culture and biomaterials design principles.

\section{Hepatocyte coculture}

Another avenue of hepatocyte cell culture research focused upon the recapitulation of the normal hepatocellular milieu by examining cell-cell interactions (Fig. 1). The functional unit of the liver is the hepatic sinusoid, which is comprised of liver capillaries or sinusoids lined by specialized, liver sinusoidal endothelial cells, which contain unique pores (fenestrations) that facilitate material exchange. Between the endothelial lining and the microvilli-bearing hepatocyte, is an extracellular space known as the Space of Disse, and specialized supporting cells known as hepatic stellate cells. Hepatic stellate cells are present on the basal (sinusoidal facing) surface of the hepatocytes. Bile canaliculi combine to form intrahepatic ducts, lined by hepatobiliary duct cells, which carry the bile produced by the hepatocytes. Not surprisingly, initial hepatic coculture studies demonstrated stable hepatic functions $[36,37]$. Building on this, three dimensional coculture systems sprang forth which relied specifically on both aggregate hepatocyte culture and interactions between hepatocytes and liver sinusoidal endothelial cells [38]. A third coculture approach utilized a transwell configuration to mimic not only the appropriate sinusoid cell 
types, but also the actual sinusoid geometry [39]. The choice of coculture cell type and configuration was found to differentially modulate hepatic specific functions [40]. In fact, cocultivation of hepatocytes and liver sinusoidal endothelial cells, in specific culture orientations, led to 10 times higher albumin function and 20 times higher CYP 1A1/2 cytochrome activity compared to controls [41]. interactions between hepatocytes and endothelial cells interactions have been shown be mediated by both growth factors [38] and intercellular amino acid transport [42].

With the success of cocultures but the need for enhanced cellular organization, engineers began to apply microfabrication technology for high level control of cellular level processes, such as cell-cell, nonparenchymal cell-cell (heterotypic), and cell-matrix interactions. These approaches served to preserve, modulate and enhance hepatocyte-specific functions [43, 44]. Further, these new techniques enabled further investigations of the science behind cellular interactions, which was possible through precise engineering and cell surface modification $[45,46]$. These seminal studies primarily focused on fibroblast cocultivation, particularly with the specialized, NIH 3T3-J2 cell line, which uniquely boosts hepatic specific functions through cell-cell contacts with potential mechanisms explored [47, 48]. These microfabricated coculture systems have shown a great deal of utility in disease modelling $[49,50]$ and therapeutic applications [51].

\section{Bioartificial liver}

Acute hepatic failure is accompanied by the loss of hepatic specific functions and disruption of basic liver physiology leading to complications and eventually death (Fig. 3). As early as the 1950's, scientists experimented with a bioartificial liver (BAL) for support of hepatic failure [52]. The first BAL consisted of cross hemodialysis between blood from a living dog and an encephalopathic dog. Subsequently, a cirrhotic patient with hepatic coma was cured by a similar system [52]. Modern BAL systems contain hepatocytes in an extracorporeal support system, and design parameters include device structure and design, species of cell (human or xenogeneic), cell type (primary vs. transformed vs. cancer line), hepatocyte configuration (adherent vs. immobilization vs. encapsulation), cell mass, perfusate contents (whole blood versus plasma) and perfusion duration [53-56]. As stated above, the mass of hepatocytes required is $10 \%$ of liver weight [7]. Other core engineering concepts include cryopreservation of hepatocytes and of BAL devices [57-59], mass transport within the device, blood constituents, and their effects on liver function [25, 60], and integration of microfabrication technology with bioreactor design [61]. The studies in patients have been limited, but positive. For example, a BAL comprised of primary porcine hepatocytes demonstrated no toxic effects and functioned as a bridge to transplantation when used intermittently in patients [62]. A prospective, randomized, multicenter clinical trial of microcarrier attached, porcine hepatocytes demonstrated no difference between study groups, but again demonstrated safety, in addition to improvements in patient subsets of fulminant/sub-fulminant failure [63]. Finally, a promising recent preclinical BAL utilizing pig hepatic spheroids in a porcine acute liver failure model demonstrated that BAL support improved survival [64]. These studies indicate the BAL is a safe and promising temporary support for acute liver failure, and continued re-engineering of design, as well as randomized, double blinded clinical studies, are needed to demonstrate efficacy.

\section{Hepatocyte transplantation}

The establishment of techniques for hepatocyte isolation, together with the development of animal models of liver failure, led to experimental hepatocyte transplantation (HCT). A detailed analysis of HCT has been reviewed elsewhere $[65,66]$. HCT has utility for both temporary support for acute liver failure, and potentially for long term functional replacement for chronic liver diseases (Fig. 2). Initial attempts at liver transplantation of partial autografts, or portions of the liver, demonstrated lack of vascularization, cellular death and scarring $[67,68]$. In contrast, initial studies of HCT demonstrated feasibility and therapeutic effect when delivered via portal vein in Gunn rats, which lack the liver enzyme uridine diphosphate glucuronyl transferase [69]. These Gunn rats function as a model of Crigler Najjar Syndrome, a rare congenital, autosomal recessive disorder of bilirubin metabolism. Positive benefits were identified not only in the Gunn rat model, but also in other acute liver failure models [70]. While initial studies employed intraportal and intraperitoneal injection, intrasplenic HCT also developed as an alternative transplant location [71]. The mechanism by which HCT worked was by the manifestation of liver nodules by transplanted hepatocytes, with maintained cellular ultrastructure [72]. Further characterization of these nodules was possible with suppression of endogenous hepatocyte replication by retrorsine after HCT and partial hepatectomy. These studies quantified the growth kinetics of donor hepatocyte cell clusters as they form intrahepatic nodules. 20-50 cells per cluster were present after two weeks, 100 cells per cluster were present at 1 month, and up to several thousand cell per cluster (representing $40-60 \%$ of hepatic mass) were present at 2 months. Further the investigation of regeneration demonstrated that soluble factors from supernatants of hepatocyte cultures can reverse liver injury, indicating complex and 


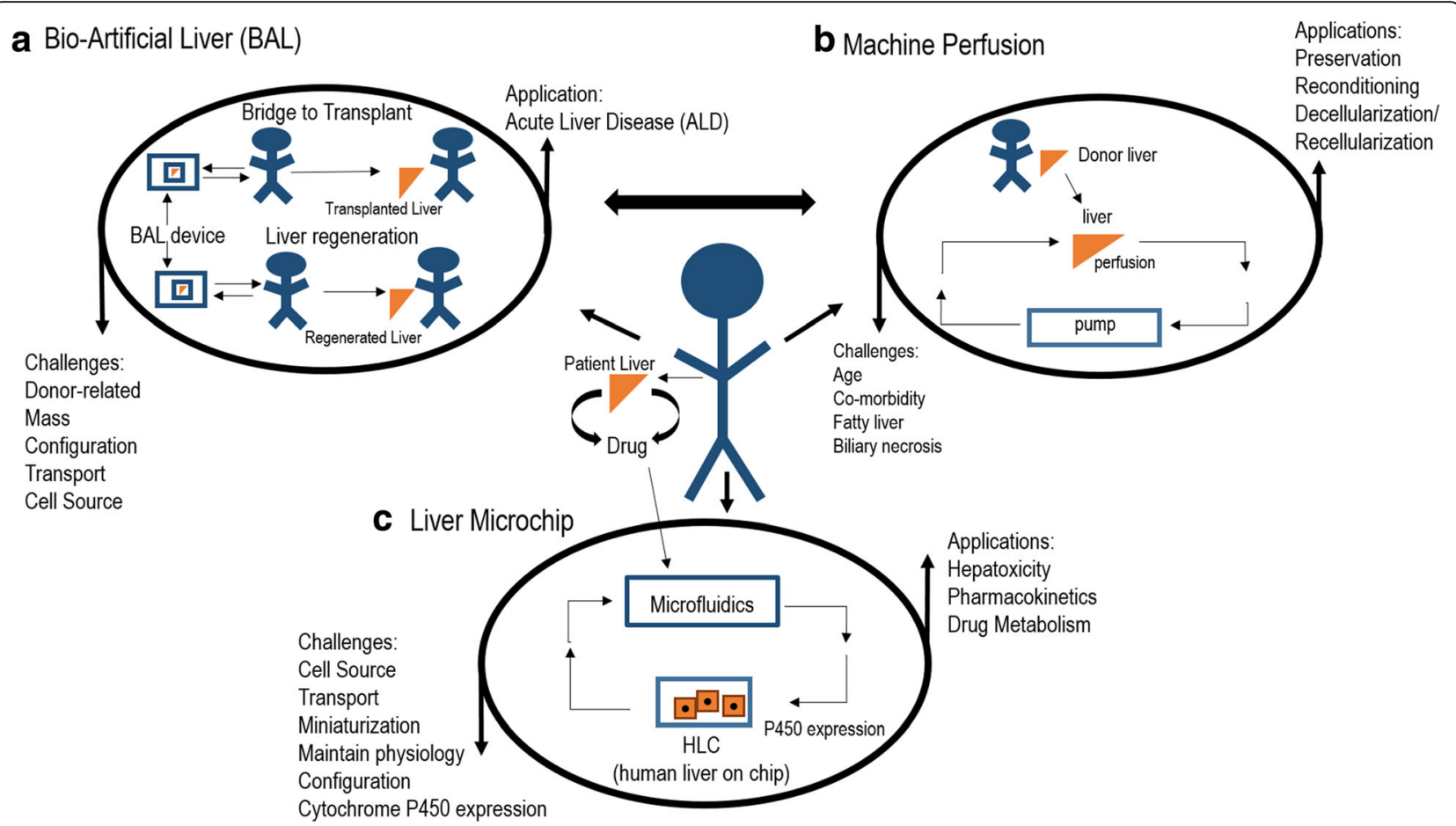

Fig. 3 Engineered liver devices. a Bioartificial liver. Engineered liver devices are at different scales and have a wide range of applications. The Bioartificial Liver (BAL) is a bioreactor system which bears hepatocytes in a variety of formats (hollow fiber vs. spheroid vs. monolayer culture). A large number of hepatocytes, approximately $10 \%$ of the adult liver, are needed to provide appropriate level of functions. Typically, the BAL is used for acute liver disease. In this case, it can be used a bridge to transplant, or as a way to regenerate acutely injured liver. The main challenges and applications are as shown. b Machine Perfusion. This is a technique used for several applications in animal models. The whole liver is connected to the perfusion device and perfusate is oxygenated and pumped to perfuse the whole liver under hypothermic or normothermic conditions. The technique is used to preserve organs after harvest, as opposed to storage of organs without flow in organ preservation solution. Machine perfusion is also used to condition marginal livers, for example by adding medium components to reverse fatty liver disease in a donor liver. Finally, machine perfusion can be used to understand complex, whole liver metabolic functions by measuring metabolites at inlet and outlet of the device under various experimental conditions. The main challenges and applications are as shown. $\mathbf{c}$ Hepatocyte Microdevices. This is a technique in which the hepatocytes are placed within miniature microfabricated devices so that they display physiological functions. Both animal and human liver on a chip applications are possible, and are valuable for assessing hepatotoxicity, drug metabolism, and pharmacokinetics, in the setting of drug discovery. These devices can potentially replace animals in the drug discovery pipeline. Patient-specific hepatocytes can be used to understand how genetic variations effect drug metabolism. Multiple cell types can be used in a circuit to better model the human body. The main challenges and applications are as shown

compensatory liver regeneration mechanisms [73]. To improve HCT for long term function, investigators attached hepatocytes to microcarriers [74], which could then be encapsulated [75, 76], as another HCT approach for liver disease. The identification and development of transgenic mouse disease models furthered the field, including the Gunn Rat, and the analbuminemic (albumin deficient) mice for measuring albumin production solely from transplanted hepatocytes, and immunodeficient animals for human HCT in rodents. Biomaterials and chemical technologies have also been used to improve HCT. Encapsulation is a technique in which cell mass can be incorporated into a semipermeable biopolymer droplet, often with a protective coating [77]. Encapsulation of hepatocytes [78], enables immunoisolation and intraabdominal cell transplantation [79], with maintained hepatocellular functions [80, 81].

Based on strong preclinical research, several clinical trials of HCT have been completed, indicating favourable regulatory approval and safety. Patients with acute liver failure benefit from hepatocyte infusions that provide weeks to months of support, as borne out by studies of auxiliary liver transplant in acute liver failure [7]. On the other hand, HCT in end stage liver disease, is likely hindered by the underlying pathology, including portal hypertension and highly abnormal tissue architecture. These cell transplantation studies demonstrate that efficient cellular delivery and engraftment are essential to improved therapeutic outcomes. The wide range of transplant locations used include intraperitoneal, intrasplenic, and intraportal and may affect cell engraftment [82].

\section{Mouse liver repopulation with hepatocytes}

A series of studies with transgenic mice led to detailed analysis of hepatocyte repopulation ability within the liver of transgenic hosts (Fig. 2). Albumin-uroplasminogen activator (Alb-uPA) mice, which bear a hepatotoxic 
(uPA) gene, was the first model used [83]. Homozygous Alb-uPA mice died due to neonatal hepatocellular injury, while hemizygote Alb-uPA mice displayed hepatic nodules with liver function due to transgene inactivation. Each hepatic nodule was clonal, derived from a single hepatocyte lacking Alb-uPA gene expression. Transplanted adult hepatocytes in neonatal (1-2 week old) Alb-uPA mice demonstrated liver repopulation capacity at 5-7 weeks [84]. In this study, transgenic (genetically marked) hepatocytes were transplanted in the spleen and identified in in excised liver tissues. Liver nodules of the donor hepatocytes were generated at the expense of Alb-uPA expressing, injured, endogenous hepatocytes. Approximately twelve population doublings $(\sim 80 \%$ liver replacement) occurred per transplanted hepatocyte. In comparison, one or two doublings occur after hepatectomy/regeneration, and less than twenty-eight doublings replace total mouse hepatocyte mass in mice. This indicates the enormous repopulation capacity of primary hepatocytes.

Further investigation of repopulation was enabled by continued development of transgenic models, one of which was the Fah -/- mouse, a model of hereditary tyrosinemia type $1[85,86]$. Fah $-/-$ mice normally die from neonatal, hepatocellular injury, due to fumaryl acetoacetate hydrolase (Fah) deficiency, but are rescued with NTBC (2-(2-nitro-4-trifluro-methylbenzoyl)-1, 3cyclohexanedione), which blocks tyrosine metabolism. NTBC treatment enables Fah -/- adult mice to maintain health, but when NTBC is withdrawn, adults die of liver failure in two months. In this model, when Fah + wildtype hepatocytes are transplanted intrasplenically and NTBC is withdrawn, they outcompete the endogenous Fah -/- hepatocytes and repopulate the Fah -/- liver. Moreover, NTBC administration suppresses the repopulation effect. In these seminal studies, the minimum number of cells required for liver repopulation was 1000 cells, and repopulation occurred between 4 and 8 weeks after transplantation. In fact, the repopulation capacity of hepatocytes was shown to be sixty-nine and eighty-six doublings in the Fah -/model [86], enough repopulations to account for several livers. Furthermore, Fah gene delivery in these Fah -/mice resulted in Fah + hepatocyte repopulating nodules. The crossing of this mouse with immunodeficient mice resulted in the FRG (Fah -/- Rag 2 -/- Il2rg -/- mouse). In FRG mice, human hepatocyte repopulation was demonstrated, leading to generate chimeric, human in mouse (HIM) livers [87]. In these HIM livers, human albumin serum levels and P450 enzymatic activity were found to correlate with percent of human hepatocyte repopulation. Other transgenic models were developed and furthered our understanding of liver repopulation including the TK-
NOG (albumin thymidine kinase transgenic-NOD-SCIDinterleukin common gamma knockout) mouse [88], and the AFC8 (FKBP-Caspase 8 gene supported by albumin promoter) mouse. Thus far, these HIM liver models are powerful tools for the study of human drug metabolism [89], hepatitis [90], malaria [91] and familial hypercholesterolemia [92], amongst others. Most recently, these transgenic systems have been applied to generate large animal (swine) models with repopulated livers [93].

Not surprisingly, these HIM models have been commercialized for these numerous applications. Yecuris (Tualatin, OR, www.yecuris.com) was founded in 2007 to commercialize the FRG technology. Hera Bio Labs (Lexington, KY, http://www.herabiolabs.com) founded in 2015, performs precision toxicology services with gene edited animal models, and is currently developing rat analogs of transgenic mouse liver repopulation models. IMODI (France, http://www.imodi-cancer.org) is a French consortium which uses the TK-NOG liver humanized model, for generating human specific profiles of chemotherapeutics. KMT Hepatrhc (Edmonton, Alberta CA, http://www.kmthepatech.com) developed the KMT Mouse ${ }^{\text {tw }}$, uses the uPA+/+/SCID mouse to generate a chimeric mouse with a humanized liver. These preclinical HIM tools are being widely utilized for drug discovery, development and preclinical.

\section{Cell-based liver therapies}

The growth in adult and pluripotent stem cell (PSC) biology and the boom in cell therapies has reinvigorated the field of liver cellular therapy. Identifying a robust hepatocyte cell source is a significant bioengineering challenge within the field of liver cell and tissue therapy. A wide range of cell types in preclinical and clinical models have thus far been utilized (adult hepatocytes, fetal hepatocytes, bone marrow-derived cells, adult stem/progenitor cells) (Fig. 2). Donor variability and marginal donor sources are major impediments to obtaining transplantable hepatocytes. Primary hepatocytes are needed in large quantities, and do not replicate in vitro. However, recent studies demonstrate appreciable in vitro hepatocyte expansion [94-96], but these approaches have not yet been adopted for widespread use. Another solution is the immortalization of primary hepatocytes which confers proliferative capability, via conditional or constitutive upregulation of immortalization genes $[97,98]$. Although these immortalized hepatocytes exhibit unlimited replication and represent a uniform cell source, they exhibit decreased hepatic functions and carry increased risks for tumorigenesis [98-100]. Xenogeneic (porcine) hepatocytes are an additional hepatocyte cell source. However, differences between physiological functions and responsiveness of porcine hepatocytes in a human environment is a major concern [101], 
although they also represent an endless supply of isogenic and uniform hepatocytes. Further, these hepatocytes can be either genetically engineered [102] or encapsulated [76], to evade the immune system. Fetal liver progenitor cells (hepatoblasts) have also emerged as an alternative to primary hepatocytes given their proliferative capacity and predisposition to develop into both hepatocytes and cholangiocytes (Fig. 2) [103]. They have been used to repopulate the liver of immunosuppressed rats and mice [104], and used in clinical studies. However, to be valuable as a cell source, these fetal progenitor cells need to be uniform with respect to age, proliferative capacity, and donor matching.

\section{Adult liver stem/progenitor cells}

Adult, resident, liver stem/progenitor cells (LSC) are also candidates for liver cell therapy in preclinical and clinical studies (Fig. 2). Normally, quiescent, self-renewing adult stem cells reside in tissues and play a key role in replenishing tissues and maintaining tissue homeostasis, in tissues like the bone marrow, intestine, and skin. In acute liver injury, hepatocytes contribute to normal liver homeostasis through replication, functioning like a stem cell. However, in chronic injury, particularly in rat and in human liver, not only do hepatocytes replenish liver tissue, but also LSC may play a greater role. LSC take the form of bipotent, small, oval shaped, progenitor cells which express cytokeratins and give rise to cells from the hepatic and biliary lineage [105]. Foxl1 has been shown to be a marker in this bipotent stem cell population [106]. Further, the cells lining the intrahepatic and extrahepatic duct contain Sox9 positive progenitor cells, and contribute to bile duct and hepatocyte homeostasis as shown by lineage tracing in mouse models [107]. Another key LSC population is biliary tree stem cells (BTSC), which are quiescent, self-renewing stem cells that reside in the peribilliary glands, and may give rise to hepatic/stem progenitor cells [108]. Clinical liver cell therapy studies with these BTSC, marked by Lgr5 (Leucine-rich repeat-containing G-protein coupled receptor 5), EpCAM (Epithelial cell adhesion molecule), and pluripotency genes like Oct4, Sox2, are in progress. Collectively, these studies of LSC subtypes demonstrate several investigators contributions to animal models of hepatocellular injury, the subtleties of the responses in the different models, the difficulty of tracking and analyzing small numbers of multipotent cells, and the promise for liver therapies [108].

\section{Pluripotent stem cell (PSC) technologies}

The advent of pluripotent stem cell (PSC) technologies has greatly accelerated the development of a selfrenewable liver cell source (Fig. 4). The origins of PSC technologies began with the development of nuclear transfer techniques that enabled cloning of organisms, termed reproductive cloning. In seminal studies, the nucleus from a frog blastomere was transplanted into enucleated frog oocytes and generated early cleavage embryos [109], and building on this, an adult, somatic nucleus was reprogrammed to a pluripotent state [110]. A blastocyst generated by this reprogrammed, somatic nucleus was transplanted into a pseudopregnant mouse, giving rise to a clone with a genome of the donor nucleus [111]. These techniques enabled the production of cloned animals, and eventually, transgenic mice, and furthered our understanding of pluripotency. The next scientific contribution was the isolation of a pluripotent, self-renewing cell population derived from the inner cell mass of the mouse blastocyst [112, 113], called mouse embryonic stem cells (mESC). Demonstrating their pluripotency, $\mathrm{mESC}$ can give rise to all three germ layers in vitro and to a teratoma when transplanted ectopically in vivo. Further, when incorporated into chimeric blastocysts that are transplanted into pseudopregnant mice, the $\mathrm{mESC}$ genome can be passed through the germline to form new clones. Success of $\mathrm{mESC}$ derivation led to derivation of $\mathrm{mESC}$ from other species, including rat, cow, and pig. Similarly, human ESC were isolated from human embryos, normally discarded from in vitro fertilization centers and culture techniques were established [114]. Scientists then determined the culture conditions for ESC to self-renew and maintain pluripotency in vitro. Despite their potency, hESC brought about ethical issues because of their association with discarded human embryos.

The development of techniques to reprogram adult cells to PSC developed [115], as this would bypass ethical issues and improve patient-specific treatments (Fig. 4). In one approach, termed cell fusion, adult fibroblasts are fused with ESC, resulting in activation of pluripotency in the somatic nucleus. However, the resulting pluripotent cell is a heterokaryon [116]. In parallel, a potent, widely used approach developed for generating self-renewing, patient-specific PSC, from any donor cell type. Reprogramming of mature, somatic cells by introduction of 4 transcription factors simultaneously, resulted in induced pluripotent stem cells (iPSC). Since these iPSC could be generated without destroying human embryos, a new field within PSC biology [117, 118]. Nevertheless, both ESC and iPSC could be interchangeably used in PSC differentiation protocols.

The usefulness of PSC for liver differentiation is based upon fundamental studies of soluble factors and transcription factors that govern mouse liver organogenesis [119], as PSC in vitro follow highly regulated, developmental programs that normally occur in vivo. Liver differentiation protocols, based on these pathways, directed 


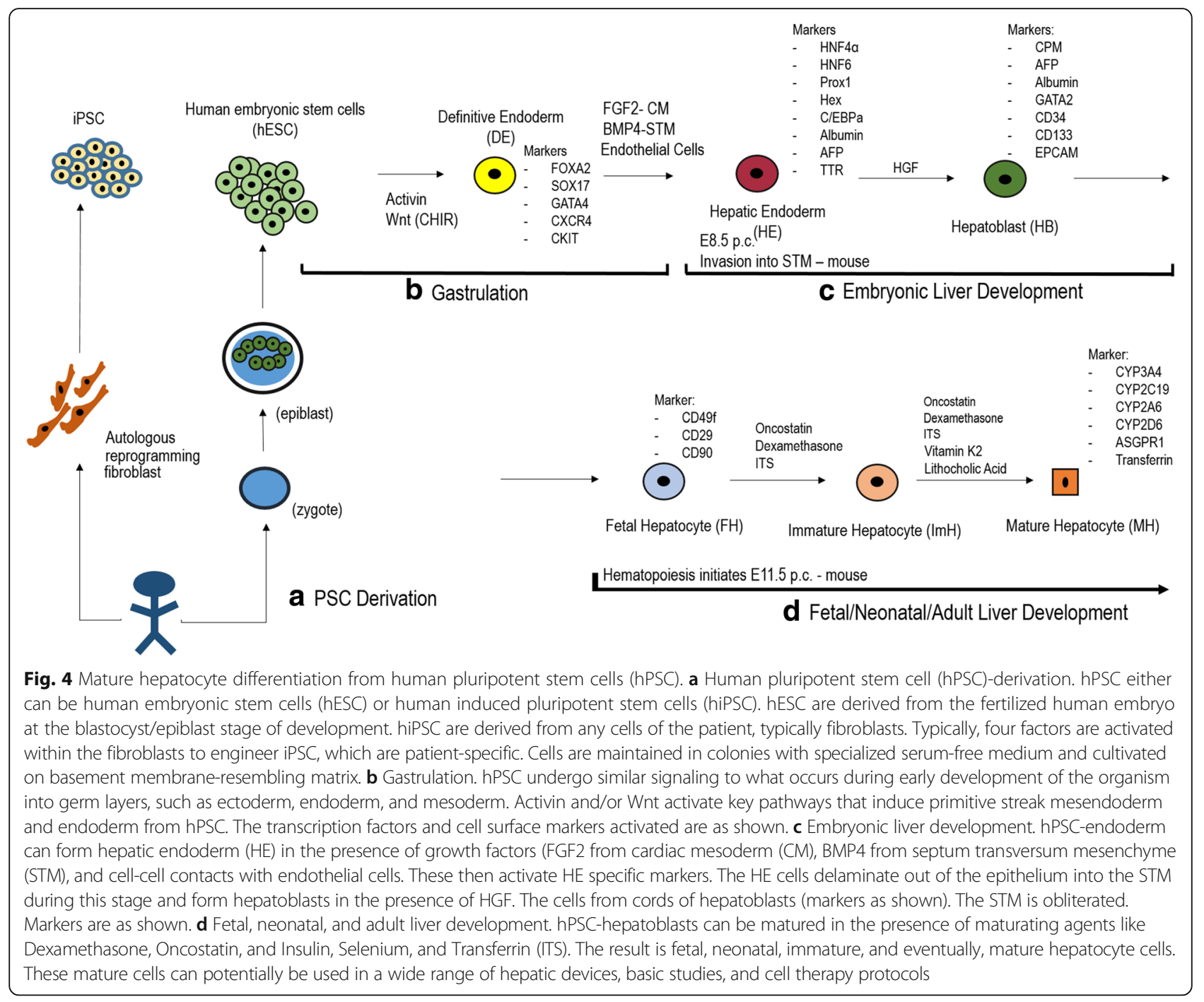

mouse ESC towards liver-like cells [120-122]. In these studies, stable transplantation of cells into liver tissue and enhanced survival of animals in liver disease models [123-125]. Further studies focused on the nature of the earliest progenitors of the liver, the definitive endoderm, from mouse and human PSC studies, about which little was known [125-129]. The study by Parashurama et al. [128] was one the first demonstrating that mESCderived endoderm progenitor cells, upon transplantation, can give rise to three dimensional, vascularized tissues, and the study by Cho et al. [125] was the first to demonstrate a specific technique for rapid mESCderived endoderm expansion. hPSC studies (hESC or hiPSC) used similar approaches [130] based upon original mouse differentiation protocols, with the creative use of small molecules [96] reprogramming approaches [131], and extracellular matrix systems. Not only could PSC be differentiated towards the liver lineage, but also other approaches were developed.
Transdifferentiation, or directed reprogramming of hepatocytes from fibroblasts, was established using key liver specific transcription factors [115, 132]. Directed differentiation protocols resulting in liver differentiation demonstrated liver specific morphology and gene expression [130]. However, limitations have been the lack of fully mature hepatocyte functions, including albumin secretion, P450 activity, urea function, and the inability to fully repopulate the liver upon transplantation in transgenic liver injury models. Despite their lack of maturity, PSC-derived hepaticlike cells have successfully been employed in approaches to model liver diseases in vitro [133].

\section{Hepatotoxicity and engineered microdevices}

Cell based systems are useful for applications requiring in vitro models that mimic liver functions (Fig. 3). Pharmaceuticals which mediate drug induced liver injury (DILI) are a major public health problem with 
heightened focus in recent academic and industrial research [134]. The liver is a central player in drug metabolism, and employs the Phase I system which is a mixed function oxidase system, including the P450 enzymes, and Phase II involving conjugation for improved solubility and drug excretion. Not surprisingly, hepatotoxicity is the number one reason that medications are withdrawn worldwide [135]. Traditional models of hepatotoxicity testing employs isolated microsomes which contain key detoxification enzymes, liver cancer cell lines, isolated primary hepatocytes, and liver slices [136]. However, several approaches applying bioengineering principles are in development to improve hepatotoxicity testing. Real commercially available products of engineered hepatocyte based systems are offered by several companies, including Regenemed (http://www.regenemed.com, San Diego, CA), InSphero (https:// www.insphero.com, Schlieren, Switzerland), and Hepregen (http://www.hepregen.com, Medford, MA). These companies employ co-culture, plate based two dimensional, or three dimensional systems, characterized by various culture configurations composed of hepatocytes and nonparenchymal cells.

While these techniques can be considered static, more dynamic systems exist which employ cell culture, microfluidic technology, and bioreactor approaches. Flow-based systems which mimic oxygen and nutrient transport, and waste exchange, demonstrate improved cell culture parameters [137]. Cell Asic (Hayward, CA) $[138,139]$ uses microfabricated porous channels which function as artificial endothelial barriers to protect hepatocytes from shear effects with improved nutrient exchange. Similarly, a device by $\mathrm{CN}$ Bio Innovations Ltd. (http://cn-bio.com/cn-bio-launch, Oxfordshire, UK) pumps medium from a reservoir to a reaction chamber, which bears cocultured hepatocytes. Hurel (http://hurel corp.com, Beverley Hills, CA) cocultures hepatocytes in microfluidic small scale cell culture analogs $(\mu \mathrm{CCA})$. These $\mu$ CCA can be integrated in microfluidic flow systems, with chips bearing other cell/tissue types, to better model whole body metabolism mediated by the liver. These devices show an in-vivo like metabolism in response to various drugs [140]. 3D printing approaches, which have the benefit of reduced cost and increased ability to generate layered systems, are being developed for a new generation of liver based devices. Organovo (http://organovo.com, San Diego, CA), employs 3D printing with devices bearing tissue-tissue interfaces and spatio-temporal diffusion of bio-chemicals, within a mechanically robust micro-environment [141]. Another innovation in drug metabolism studies has been at the level of cell source. The HepRG cell line is a bipotent liver cell line that, when differentiated further, better mimics hepatocytes, compared to comparable cancer cell lines. It offers uniformity of gene expression and drug metabolism, and functions as a key alternative [142, 143].

\section{Engineering considerations of hepatocytes within devices} Whether hepatocytes are cultivated within bioreactors or microdevices, in vitro bioprocessing of mature hepatocytes involves considerations of cell seeding, hepatocellular, and extracellular matrix configuration (Fig. 3). Viability, morphology, and function are major considerations within the microenvironment of these devices. In addition to monitoring changes in temperature and $\mathrm{pH}$, growth factors, oxygen, and nutrients, are essential for maintained hepatocellular functions, as is removal of waste products. Flow-based systems improved physiological modeling of liver functions, but associated biomechanical forces within these engineered microenvironments will affect cells. Hydrodynamic shear stress associated with spinning bioreactors and shear stress associated with capillary motion of cells in liver cell microchips naturally impacts cell behavior. Preclinical models of the BAL have determined how flow affects primary rat hepatocytes (cocultured with 3 T3) functions [144] in a microchannel bioreactor system. Shear stress calculations showed that low wall shear stress for the bioreactor (0.01 to $0.33 \mathrm{dyn} / \mathrm{cm}^{2}$ ) hepatocyte function measured in albumin and urea synthesis rates, were 2.6 to 1.9 times, respectively, greater than those at higher wall stresses ( 5 to $21 \mathrm{dyn} / \mathrm{cm}^{2}$ ). A follow up study validated the detrimental effects of shear stress on hepatic function, while developing grooved substrates that protect hepatocytes from shear under high flow/oxygen delivery conditions [61]. These studies highlighted shear stress effects but lacked the cellular content and geometry that is present in the liver sinusoid. Du et al. [145] created a model of the liver sinusoid, complete with a fluid channel for flow lined by liver sinusoidal endothelial cells (LSEC) and Kupfer cells lying on a porous membrane. These pores lead to a second channel with primary hepatic stellate cells and primary hepatocytes. These studies demonstrated that shear flow $\left(0.1-0.5 \mathrm{dyn} / \mathrm{cm}^{2}\right)$ enhanced albumin, HGF secretion, as well as drug metabolism, but not urea secretion. However, oxygen transport was not modeled in this study. Overall, micro-engineered organ on a chip technology that integrates defined 3D microarchitecture, hepatocytes, microscale interactions, and microfluidics, report enhanced liver functions in the presence of oxygen and shear flow.

\section{Decellularized liver grafts}

A new approach in liver regenerative medicine is generating three dimensional tissue with a decellularized, native liver bioscaffold, that can be re-seeded with appropriate parenchymal and nonparenchymal cells (Fig. 3). This whole organ approach may enable scientists to 
salvage marginal livers, or perhaps even xenogeneic livers for therapeutic use. Although decellularization has been used since the 1980's [146], the first report of whole organ decellularization and recellularization resulted in a functional heart and opened up a new field in bioengineering and medicine [147]. Using similar techniques, scientists generated the first decellularized, and recellularized liver [148]. Here, ischemic liver decellularization with perfusion of sodium dodecyl sulfate (SDS) detergent preserved the chemical composition and structure, with structurally intact vessels, and bile ducts, and was recellularized with hepatocytes as well as microvascular endothelial cells under perfusion. The recellularized graft was transplanted for eight hours in vivo, perfused ex vivo for twenty hours, and demonstrated mature liver functions. Follow up studies demonstrated multistep cell seeding with proliferative hepatocytes, the presence of the biliary tree, a milder decellularization cocktail, the use of a cryopreserved, rather than ischemic, donor liver [149], and further process improvements $[150,151]$. In bringing the approach to clinical scale, pig livers have been processed in a similar way [152]. These studies point towards success in the preclinical small and large animal studies, and fundamental limitations, such as seeding and in vivo survival, that are actively being addressed.

\section{Conclusions}

In this review, we summarize the history and key publications within liver regenerative medicine. We summarize seminal studies in areas as diverse as liver perfusion and hepatocyte isolation, liver regeneration, bioartificial liver, liver transplantation, and cell therapies. These subjects have in part forged the field liver regenerative medicine. The largest discriminating factor in liver regenerative medicine is the shear mass of the liver, as it is a solid organ with $\sim 2 \times 10^{11}$ cells in a $70 \mathrm{~kg}$ male. Its vast size together with complex hepatocellular functions, including detoxification, whole body metabolism, digestion, and protein synthesis, naturally constrain in vitro models and therapeutic solutions. Below we analyze aspects of liver regenerative medicine some future areas of growth.

In terms of liver transplantation, the lack of donor livers has focused attention upon increasing donor pool through advancing living donor related transplantation, reconditioning marginal livers using machine perfusion, and whole organ decellularization. We speculate that improvement in this area could be achieved, conceptually, by combining transplantation technology, with liver regeneration fundamentals, and organ preservation technology. If donor tissue can be divided surgically into smaller transplantable units, could make several hepatectomized transplants available. If this hepatectomized transplant can be appropriately anastamosed to the hepatobiliary ducts, and both the portal and the systemic circulatory systems in a matched organ transplant recipient, then more transplants from an initial donor organ might be available. Approximately $10 \%$ of liver mass may be needed to maintain liver functions. Here, perhaps improved knowledge of liver regeneration could be used to grow the miniature transplant in the patient. The other transplantable units could be maintained through storage techniques and transplanted either at the same time in matching patients or at a future time. Further, perhaps transplantable units could be regenerated ex vivo using perfusion technology (see below). This approach could be used to salvage donor tissue, and potentially preserve tissue for multiple operations. As it stands now, donor limitations are a major problem and will continue to be.

A major area of potential, continued growth will likely be machine perfusion technology [153]. Storage under perfusion could reduce serial aspects of organ injury that occur during storage and transplantation [154]. Further, changes in donor pool, reflected by organs from older patients, donors with more concomitant disease, donors with steatohepatitis, and donors from non-heart beating donors, could all have a higher risk of delayed graft functions, [153]. and thus machine perfusion could address this problem [155]. Most liver transplant centers are not yet equipped with this technology. Opportunities in this area could be methods for making the process inexpensive and extending perfusion time. Furthermore, the roles of the perfusate type, oxygenation and temperature of perfusate, pressure versus flow based control of perfusate, length of perfusion, and assessment of metabolic parameters measured all are under investigation [153]. Machine perfusion has also been used to generate decellularized livers and potentially recellularized livers which is a likely growing application of this technology [156].

Although BAL technology for acute liver failure is again reaching the pre-clinical stage, there remain many challenges for clinical implementation. Here, the BAL could serve as a bridge to transplantation, or as a therapeutic intervention to improve symptoms. From a practical point of view, if a patient is diagnosed with acute liver failure (ALF) in a community hospital, rapid hepatocellular injury and subsequent encephalopathy would occur on a time scale of a week (hyperacute) to a month (subacute) [157]. Therefore, the patient would likely need to be sent to a liver specialty center and receive a BAL within days of diagnosis. The greatest limitation here is that a large cell mass, approximately $2 \times 10^{10}$ functional hepatocytes, would need to be readily available. In the Glorioso et al. study [158], allogeneic porcine hepatocytes were used, and each swine that received BAL therapy required one swine donor liver to generate the high density hepatocyte culture within the BAL. If high density hepatocyte spheroid cultures can 
be rapidly deployed within $24 \mathrm{~h}$ as they were in the Glorioso et al. study, then perhaps this approach can be utilized clinically, because it fits with time in which patient's with ALF develop symptoms. Probably porcine hepatocytes, or even better, human hepatocytes could be used in this BAL approach. Obtaining a large number of human hepatocytes in such a short amount of time would be problematic. However, liver repopulation has been accomplished in mice, rats, rabbits, and pigs [93]. It may be possible to also repopulate human hepatocytes in immunodeficient large animals as is done in mouse. If these animals, or the cells within them can be transported rapidly, it would be possible to obtain a large amount of hepatocytes that would be needed for a BAL to function.

There remains to be potentially valuable contributions for cellular therapies and stem cells in liver regenerative medicine. An effective use of HCT is acute liver failure. A major impediment is large numbers of an allogeneic hepatocyte cell source that would be required, and associated immunosuppression. As mentioned above, the only way to expand human hepatocytes to large quantities is with in vivo liver repopulation within immunodeficient, transgenic large animals. However, human hepatocytes would have to be recovered without any associated pig antigens, and at this time it is not $100 \%$ clear if this is possible. Genetically modified pigs, perhaps without hepatocyte MHC I or without cell surface carbohydrates that induce a hyperacute immune reaction, could also be potentially be used as a source of hepatocytes for human transplantation. However, associated immunosuppression would be required. The advantage of this approach compared to the BAL for acute liver failure would be cost, ease of application, and the fact that human hepatocytes from the same swine donor liver could potentially be used for another patient simultaneously.

hPSC are promising because they are self-renewable, and thus hPSC-based approaches to generate mature hepatocytes or mature liver tissue are advantageous. This would impact several major fields within liver regenerative medicine. As a central cell source for devices, like the BAL and human liver on a chip, and a source for hepatocyte cell therapy, this would be a major achievement in liver regenerative medicine. New methods to differentiate hPSC to hepatocyte-like cells [159] or to improve maturation of hepatocytes are likely to be important to generating fully functional hepatocytes [160]. These types of studies will be a key development within liver regenerative medicine. The fact that several hepatocyte-based approaches have led to several commercialization efforts, indicate that there is an indeed a "market" for liver cells/tissue at a time when liver diseases are escalating. As scientists, engineers, and physicians continue to work together on creative solutions, we expect further development of new technologies that will advance the field for improved patient care of patients with liver disease.

\begin{abstract}
Abbreviations
Alb-uPA: Albumin-Uroplasminogen Activator; BTSC: Biliary tree stem cells; CLD: Chronic Liver Disease; CYP: Cytochrome P450 Enzymes; DILI: Drug induced liver injury; EpCAM: Epithelial cell adhesion molecule; FAH: Fumaryl acetoacetate hydrolase; FRG: (Fah -/- Rag 2 -/- IIrg -/- mice; HCC: Hepatocellular Carcinoma; HCT: Hepatocyte cell transplantation; HIM: Human in mouse; iPSC: Induced pluripotent stem cells; Lgr5: Leucinerich repeat-containing G-protein coupled receptor 5; LSC: Liver stem/progenitor cells; NAFLD: Non-alcoholic Fatty Liver Disease; NASH: Non-alcoholic Steatohepatitis; NTBC: (2-(2-nitro-4-trifluro-methylbenzoyl)-1, 3-cyclohexanedione); PSC: Pluripotent stem cells; SDS: Sodium dodecyl sulfate; $\mu$ CCA: Micro-fluidic small-scale cell culture analogs
\end{abstract}

\section{Acknowledgements}

Not applicable.

\section{Funding}

University at Buffalo Startup Funds.

Availability of data and materials

All data generated or analyzed during this study are included in this published article.

\section{Authors' contributions}

$\mathrm{OO}, \mathrm{JO}$, and NP conceived of, wrote and edited the manuscript. NP approved this manuscript. All authors read and approved the final manuscript.

\section{Competing interests}

The authors declare that they have no competing interests.

\section{Publisher's Note}

Springer Nature remains neutral with regard to jurisdictional claims in published maps and institutional affiliations.

\section{Author details}

${ }^{1}$ Department of Chemical and Biological Engineering, University at Buffalo (State University of New York), Furnas Hall, Buffalo, NY 14260, USA. ${ }^{2}$ Clinical and Translation Research Center (CTRC), University at Buffalo (State University of New York), 875 Ellicott St., Buffalo, NY 14203, USA. ${ }^{3}$ Department of Biomedical Engineering, University at Buffalo (State University of New York), Furnas Hall, 907 Furnas Hall, Buffalo, NY 14260, USA.

Received: 6 April 2017 Accepted: 25 September 2017

Published online: 26 November 2017

\section{References}

1. Murray CJL, Lopez AD. Alternative projections of mortality and disability by cause 1990-2020: Global Burden of Disease Study. Lancet. 1997;349(9064): 1498-504.

2. Milic S, Mikolasevic I, Krznaric-Zrnic I, Stanic M, Poropat G, Stimac D, Vlahovic-Palcevski V, Orlic L. Nonalcoholic steatohepatitis: emerging targeted therapies to optimize treatment options. Drug Des Devel Ther. 2015;9:4835-45.

3. Durand F, Francoz C. The future of liver transplantation for viral hepatitis. Liver Int. 2017;37(Suppl 1):130-5.

4. Aday AW, Mitchell MC, Casey LC: Alcoholic hepatitis: current trends in management. Curr Opin Gastroenterol 2017;33(3):142-8.

5. Best J, Schotten C, Theysohn JM, Wetter A, Muller S, Radunz S, Schulze M, Canbay A, Dechene A, Gerken G. Novel implications in the treatment of hepatocellular carcinoma. Ann Gastroenterol. 2017;30(1):23-32.

6. Sohlenius-Sternbeck A-K. Determination of the hepatocellularity number for human, dog, rabbit, rat and mouse livers from protein concentration measurements. Toxicol in Vitro. 2006;20(8):1582-6.

7. Asonuma K, Gilbert JC, Stein JE, Takeda T, Vacanti JP. Quantitation of transplanted hepatic mass necessary to cure the Gunn rat model of hyperbilirubinemia. J Pediatr Surg. 1992;27(3):298-301. 
8. Rana A, Gruessner A, Agopian VG, Khalpey Z, Riaz IB, Kaplan B, Halazun KJ, Busuttil RW, Gruessner RW. Survival benefit of solid-organ transplant in the United States. JAMA Surg. 2015;150(3):252-9.

9. Vilarinho S, Lifton RP. Liver transplantation: from inception to clinical practice. Cell. 2012;150(6):1096-9.

10. Marecki $H$, Bozorgzadeh A, Porte R, Leuvenink $H$, Uygun $K$, Martins P. Liver ex-vivo machine perfusion preservation: A review of the methodology and results of large animal studies and clinical trials. Liver Transpl 2017;23(5):679-95.

11. Toniutto P, Zanetto A, Ferrarese A, Burra P. Current challenges and future directions for liver transplantation. Liver Int 2016;37(3):317-27.

12. Michalopoulos GK, DeFrances MC. Liver Regeneration. Science. 1997; 276(5309):60-6.

13. Michalopoulos GK. Hepatostat: Liver regeneration and normal liver tissue maintenance. Hepatology 2016;65(4):1384-92.

14. Schaub JR, Malato Y, Gormond C, Willenbring $H$. Evidence against a stem cell origin of new hepatocytes in a common mouse model of chronic liver injury. Cell Rep. 2014;8(4):933-9.

15. Trowell OA. Urea formation in the isolated perfused liver of the rat. J Physiol. 1942;100(4):432-58.

16. Seglen PO. Insulin inhibition of tyrosine transaminase degradation in the isolated, perfused rat liver. Hoppe Seylers Z Physiol Chem. 1968;349(9):1229-30.

17. Jensen FC, Gwatkin RBL, Biggers JD. A simple organ culture method which allows simultaneous isolation of specific types of cells. Exp Cell Res. 1964;34(3):440-7.

18. Seglen PO. Hepatocyte suspensions and cultures as tools in experimental carcinogenesis. J Toxicol Environ Health. 1979;5(2-3):551-60.

19. Reid LM, Gaitmaitan Z, Arias I, Ponce P, Rojkind M. Long-term cultures of normal rat hepatocytes on liver biomatrix. Ann N Y Acad Sci. 1980;349:70-6.

20. Reid LM, Jefferson DM. Culturing Hepatocytes and Other Differentiated Cells. Hepatology. 1984;4(3):548-59.

21. Bissell DM, Arenson DM, Maher JJ, Roll FJ. Support of cultured hepatocytes by a laminin-rich gel. Evidence for a functionally significant subendothelial matrix in normal rat liver. J Clin Investig. 1987;79(3):801-12.

22. Dunn JCY, Tompkins RG, Yarmush ML. Long-Term in Vitro Function of Adult Hepatocytes in a Collagen Sandwich Configuration. Biotechnol Prog. 1991; 7(3):237-45

23. Foy BD, Rotem A, Toner M, Tompkins RG, Yarmush ML. A device to measure the oxygen uptake rate of attached cells: importance in bioartificial organ design. Cell Transplant. 1994;3(6):515-27.

24. Rotem A, Toner M, Bhatia S, Foy BD, Tompkins RG, Yarmush ML. Oxygen is a factor determining in vitro tissue assembly: Effects on attachment and spreading of hepatocytes. Biotechnol Bioeng. 1994;43(7):654-60.

25. Matthew HW, Sternberg J, Stefanovich P, Morgan JR, Toner M, Tompkins RG, Yarmush ML. Effects of plasma exposure on cultured hepatocytes: Implications for bioartificial liver support. Biotechnol Bioeng. 1996;51(1):100-11.

26. Stefanovich $\mathrm{P}$, Matthew HW, Toner M, Tompkins RG, Yarmush ML. Extracorporeal plasma perfusion of cultured hepatocytes: effect of intermittent perfusion on hepatocyte function and morphology. J Surg Res. 1996;66(1):57-63.

27. Koide N, Shinji T, Tanabe T, Asano K, Kawaguchi M, Sakaguchi K, Koide Y, Mori M, Tsuji T. Continued high albumin production by multicellular spheroids of adult rat hepatocytes formed in the presence of liver-derived proteoglycans. Biochem Biophys Res Commun. 1989;161(1):385-91.

28. Moghe PV, Berthiaume F, Ezzell RM, Toner M, Tompkins RG, Yarmush ML. Culture matrix configuration and composition in the maintenance of hepatocyte polarity and function. Biomaterials. 1996;17(3):373-85.

29. Abu-Absi SF, Friend JR, Hansen LK, Hu WS. Structural polarity and functional bile canaliculi in rat hepatocyte spheroids. Exp Cell Res. 2002;274(1):56-67.

30. Park A, Cima LG. In vitro cell response to differences in poly-L-lactide crystallinity. J Biomed Mater Res. 1996;31(1):117-30.

31. Ranucci CS, Moghe PV. Polymer substrate topography actively regulates the multicellular organization and liver-specific functions of cultured hepatocytes. Tissue Eng. 1999;5(5):407-20.

32. Brieva TA, Moghe PV. Functional engineering of hepatocytes via heterocellular presentation of a homoadhesive molecule, E-cadherin. Biotechnol Bioeng. 2001;76(4):295-302.

33. Semler EJ, Lancin PA, Dasgupta A, Moghe PV. Engineering hepatocellular morphogenesis and function via ligand-presenting hydrogels with graded mechanical compliance. Biotechnol Bioeng. 2005;89(3):296-307.

34. Kidambi S, Lee I, Chan C. Controlling primary hepatocyte adhesion and spreading on protein-free polyelectrolyte multilayer films. J Am Chem Soc 2004;126(50):16286-7.
35. Rajagopalan P, Shen CJ, Berthiaume F, Tilles AW, Toner M, Yarmush ML. Polyelectrolyte nano-scaffolds for the design of layered cellular architectures. Tissue Eng. 2006;12(6):1553-63.

36. Guguen-Guillouzo C, Clement B, Baffet G, Beaumont C, Morel-Chany E, Glaise D, Guillouzo A. Maintenance and reversibility of active albumin secretion by adult rat hepatocytes co-cultured with another liver epithelial cell type. Exp Cell Res. 1983;143(1):47-54.

37. Lebreton JP, Daveau M, Hiron M, Fontaine M, Biou D, Gilbert D, GuguenGuillouzo C. Long-term biosynthesis of complement component C3 and alpha-1 acid glycoprotein by adult rat hepatocytes in a co-culture system with an epithelial liver cell-type. Biochem J. 1986;235(2):421-7.

38. Nahmias Y, Schwartz RE, Hu WS, Verfaillie CM, Odde DJ. Endotheliummediated hepatocyte recruitment in the establishment of liver-like tissue in vitro. Tissue Eng. 2006;12(6):1627-38.

39. Kang YB, Rawat S, Cirillo J, Bouchard M, Noh HM. Layered long-term coculture of hepatocytes and endothelial cells on a transwell membrane: toward engineering the liver sinusoid. Biofabrication. 2013;5(4):045008.

40. Yang Y, Li J, Pan X, Zhou P, Yu X, Cao H, Wang Y, Li L. Co-culture with mesenchymal stem cells enhances metabolic functions of liver cells in bioartificial liver system. Biotechnol Bioeng. 2013;110(3):958-68.

41. Bale SS, Golberg I, Jindal R, McCarty WJ, Luitje M, Hegde M, Bhushan A, Usta OB, Yarmush ML. Long-term coculture strategies for primary hepatocytes and liver sinusoidal endothelial cells. Tissue Eng Part C Methods. 2015;21(4):413-22.

42. Jindal R, Nahmias Y, Tilles AW, Berthiaume F, Yarmush ML. Amino acidmediated heterotypic interaction governs performance of a hepatic tissue model. FASEB J. 2009;23(7):2288-98.

43. Bhatia SN, Balis UJ, Yarmush ML, Toner M. Effect of cell-cell interactions in preservation of cellular phenotype: cocultivation of hepatocytes and nonparenchymal cells. FASEB J. 1999;13(14):1883-900.

44. Kojima R, Yoshimoto K, Takahashi E, Ichino M, Miyoshi H, Nagasaki Y. Spheroid array of fetal mouse liver cells constructed on a PEG-gel micropatterned surface: upregulation of hepatic functions by co-culture with nonparenchymal liver cells. Lab Chip. 2009;9(14):1991-3.

45. Bhatia SN, Balis UJ, Yarmush ML, Toner M. Probing heterotypic cell interactions: hepatocyte function in microfabricated co-cultures. J Biomater Sci Polym Ed. 1998;9(11):1137-60.

46. Bhatia SN, Balis UJ, Yarmush ML, Toner M. Microfabrication of hepatocyte/ fibroblast co-cultures: role of homotypic cell interactions. Biotechnol Prog. 1998;14(3):378-87.

47. Khetani SR, Szulgit G, Del Rio JA, Barlow C, Bhatia SN. Exploring interactions between rat hepatocytes and nonparenchymal cells using gene expression profiling. Hepatology. 2004:40(3):545-54.

48. Hui EE, Bhatia SN. Micromechanical control of cell-cell interactions. Proc Nat Acad Sci U S A. 2007;104(14):5722-6.

49. Ploss A, Khetani SR, Jones CT, Syder AJ, Trehan K, Gaysinskaya VA, Mu K, Ritola K, Rice CM, Bhatia SN. Persistent hepatitis C virus infection in microscale primary human hepatocyte cultures. Proc Natl Acad Sci U S A. 2010;107(7):3141-5.

50. March S, Ng S, Velmurugan S, Galstian A, Shan J, Logan DJ, Carpenter AE, Thomas D, Sim BK, Mota MM, et al. A microscale human liver platform that supports the hepatic stages of Plasmodium falciparum and vivax. Cell Host Microbe. 2013;14(1):104-15.

51. Chen AA, Thomas DK, Ong LL, Schwartz RE, Golub TR, Bhatia SN. Humanized mice with ectopic artificial liver tissues. Proc Natl Acad Sci U S A. 2011;108(29):11842-7.

52. Hori M. Artificial liver: present and future. Artif Organs. 1986;10(3):211-3.

53. Chan C, Berthiaume F, Nath BD, Tilles AW, Toner M, Yarmush ML. Hepatic tissue engineering for adjunct and temporary liver support: critical technologies. Liver Transpl. 2004;10(11):1331-42.

54. Miranda JP, Rodrigues A, Tostoes RM, Leite S, Zimmerman H, Carrondo MJ, Alves PM. Extending hepatocyte functionality for drug-testing applications using high-viscosity alginate-encapsulated three-dimensional cultures in bioreactors. Tissue Eng Part C Methods. 2010;16(6):1223-32.

55. Tostoes RM, Leite SB, Miranda JP, Sousa M, Wang DI, Carrondo MJ, Alves PM Perfusion of 3D encapsulated hepatocytes-a synergistic effect enhancing long-term functionality in bioreactors. Biotechnol Bioeng. 2011;108(1):41-9.

56. Allen JW, Hassanein T, Bhatia SN. Advances in bioartificial liver devices. Hepatology. 2001;34(3):447-55.

57. Stefanovich P, Ezzell RM, Sheehan SJ, Tompkins RG, Yarmush ML, Toner M. Effects of hypothermia on the function, membrane integrity, and cytoskeletal structure of hepatocytes. Cryobiology. 1995;32(4):389-403. 
58. Russo MJ, Toner M. Cryopreservation of rat hepatocytes in a threedimensional culture configuration using a controlled-rate freezing device. Methods Mol Med. 1999;18:303-12.

59. Sugimachi K, Roach KL, Rhoads DB, Tompkins RG, Toner M. Nonmetabolizable glucose compounds impart cryotolerance to primary rat hepatocytes. Tissue Eng. 2006:12(3):579-88.

60. Chan C, Berthiaume F, Washizu J, Toner M, Yarmush ML. Metabolic preconditioning of cultured cells in physiological levels of insulin: generating resistance to the lipid-accumulating effects of plasma in hepatocytes. Biotechnol Bioeng. 2002;78(7):753-60.

61. Park J, Berthiaume F, Toner M, Yarmush ML, Tilles AW. Microfabricated grooved substrates as platforms for bioartificial liver reactors. Biotechnol Bioeng. 2005;90(5):632-44

62. Rozga J, Morsiani E, Lepage E, Moscioni AD, Demetriou AA, Giorgio T. Isolated hepatocytes in a bioartificial liver: A single group view and experience. Biotechnol Bioeng. 1994;43(7):645-53.

63. Demetriou AA, Brown RS Jr, Busuttil RW, Fair J, McGuire BM, Rosenthal P, Am Esch JS 2nd, Lerut J, Nyberg SL, Salizzoni M, et al. Prospective, randomized, multicenter, controlled trial of a bioartificial liver in treating acute liver failure. Ann Surg. 2004;239(5):660-7. discussion 667-670.

64. Lee JH, et al. "Functional Evaluation of a Bioartificial Liver Support System Using Immobilized Hepatocyte Spheroids in a Porcine Model of Acute Liver Failure." Scientific Reports. 2017;7(1):3804.

65. Soltys KA, Soto-Gutierrez A, Nagaya M, Baskin KM, Deutsch M, Ito R, Shneider BL, Squires R, Vockley J, Guha C, et al. Barriers to the successful treatment of liver disease by hepatocyte transplantation. J Hepatol. 2010; 53(4):769-74.

66. Huebert RC, Rakela J. Cellular therapy for liver disease. Mayo Clin Proc. 2014; 89(3):414-24.

67. Grisham JW, Leong GF, Hole BV. Heterotopic Partial Autotransplantation of Rat Liver: Technic and Demonstration of Structure and Function of the Graft. Cancer Res. 1964;24:1474-95.

68. Leong GF, Grisham JW, Hole BV, Albright ML. Effect of Partial Hepatectomy on DNA Synthesis and Mitosis in Heterotopic Partial Autografts of Rat Liver. Cancer Res. 1964;24:1496-501.

69. Matas AJ, Sutherland DER, Steffes MW, Mauer SM, Lowe A, Simmons RL, Najarian JS. Hepatocellular Transplantation for Metabolic Deficiencies Decrease of Plasma Bilirubin in Gunn Rats. Science. 1976;192(4242):892-4.

70. Sutherland DER, Numata M, Matas AJ, Simmons RL, Najarian JS. Hepatocellular Transplantation in Acute Liver-Failure. Surgery. 1977;82(1):124-32.

71. Mito M, Ebata H, Kusano M, Onishi T, Saito T, Sakamoto S. Morphology and Function of Isolated Hepatocytes Transplanted into Rat Spleen. Transplantation. 1979;28(6):499-505.

72. Jirtle RL, Biles C, Michalopoulos G. Morphologic and histochemical analysis of hepatocytes transplanted into syngeneic hosts. Am J Pathol. 1980;101(1):115-26.

73. Baumgartner D, LaPlante-O'Neill PM, Sutherland DE, Najarian JS. Effects of intrasplenic injection of hepatocytes, hepatocyte fragments and hepatocyte culture supernatants on D-galactosamine-induced liver failure in rats. Eur Surg Res. 1983;15(3):129-35.

74. Demetriou AA, Whiting JF, Feldman D, Levenson SM, Chowdhury NR, Moscioni AD, Kram M, Chowdhury JR. Replacement of liver function in rats by transplantation of microcarrier-attached hepatocytes. Science. 1986 233(4769):1190-2.

75. Demetriou AA, Reisner A, Sanchez J, Levenson SM, Moscioni AD, Chowdhury JR. Transplantation of microcarrier-attached hepatocytes into 90\% partially hepatectomized rats. Hepatology. 1988:8(5):1006-9.

76. Bruni S, Chang TM. Hepatocytes immobilised by microencapsulation in artificial cells: effects on hyperbilirubinemia in Gunn rats. Biomater Artif Cells Artif Organs. 1989;17(4):403-11.

77. Orive G, Santos E, Poncelet D, Hernandez RM, Pedraz JL, Wahlberg LU, De Vos P, Emerich D. Cell encapsulation: technical and clinical advances. Trends Pharmacol Sci. 2015;36(8):537-46.

78. Wong H, Chang TM. Bioartificial liver: implanted artificial cells microencapsulated living hepatocytes increases survival of liver failure rats. Int J Artif Organs. 1986;9(5):335-6.

79. Vacanti JP, Morse MA, Saltzman WM, Domb AJ, Perez-Atayde A, Langer R. Selective cell transplantation using bioabsorbable artificial polymers as matrices. J Pediatr Surg. 1988;23(1 Pt 2):3-9.

80. Sun AM, Cai Z, Shi Z, Ma F, O'Shea GM. Microencapsulated hepatocytes: an in vitro and in vivo study. Biomater Artif Cells Artif Organs. 1987;15(2): 483-96.
81. Miura Y, Akimoto T, Yagi K. Liver functions in hepatocytes entrapped within calcium alginate. Ann N Y Acad Sci. 1988;542:521-32

82. Zhang W, Tucker-Kellogg L, Narmada BC, Venkatraman L, Chang S, Lu Y, Tan N, White JK, Jia R, Bhowmick SS, et al. Cell-delivery therapeutics for liver regeneration. Adv Drug Deliv Rev. 2010;62(7-8):814-26.

83. Sandgren EP, Palmiter RD, Heckel JL, Daugherty CC, Brinster RL, Degen JL. Complete hepatic regeneration after somatic deletion of an albuminplasminogen activator transgene. Cell. 1991;66(2):245-56.

84. Rhim JA, Sandgren EP, Degen JL, Palmiter RD, Brinster RL. Replacement of diseased mouse liver by hepatic cell transplantation. Science. 1994; 263(5150):1149-52.

85. Grompe M, Lindstedt S, al-Dhalimy M, Kennaway NG, Papaconstantinou J, Torres-Ramos CA, Ou CN, Finegold M. Pharmacological correction of neonatal lethal hepatic dysfunction in a murine model of hereditary tyrosinaemia type I. Nat Genet. 1995:10(4):453-60.

86. Overturf K, Al-Dhalimy M, Tanguay R, Brantly M, Ou CN, Finegold M, Grompe M. Hepatocytes corrected by gene therapy are selected in vivo in a murine model of hereditary tyrosinaemia type I. Nat Genet. 1996;12(3):266-73.

87. Azuma H, Paulk N, Ranade A, Dorrell C, Al-Dhalimy M, Ellis E, Strom S, Kay MA, Finegold M, Grompe M. Robust expansion of human hepatocytes in Fah-/-/Rag2-/-/I2rg-/- mice. Nat Biotechnol. 2007;25(8):903-10.

88. Hasegawa M, Kawai K, Mitsui T, Taniguchi K, Monnai M, Wakui M, Ito M, Suematsu M, Peltz G, Nakamura M, et al. The reconstituted 'humanized liver' in TK-NOG mice is mature and functional. Biochem Biophys Res Commun. 2011:405(3):405-10.

89. Tateno C, Yoshizane Y, Saito N, Kataoka M, Utoh R, Yamasaki C, Tachibana A Soeno $Y$, Asahina $\mathrm{K}$, Hino $\mathrm{H}$, et al. Near completely humanized liver in mice shows human-type metabolic responses to drugs. Am J Pathol. 2004;165(3): 901-12.

90. Dandri M, Burda MR, Torok E, Pollok JM, Iwanska A, Sommer G, Rogiers X, Rogler CE, Gupta S, Will H, et al. Repopulation of mouse liver with human hepatocytes and in vivo infection with hepatitis B virus. Hepatology. 2001; 33(4):981-8

91. Good MF, Hawkes MT, Yanow SK. Humanized Mouse Models to Study CellMediated Immune Responses to Liver-Stage Malaria Vaccines. Trends Parasitol. 2015:31(11):583-94.

92. Washburn ML, Bility MT, Zhang L, Kovalev Gl, Buntzman A, Frelinger JA, Barry W, Ploss A, Rice CM, Su L. A humanized mouse model to study hepatitis $C$ virus infection, immune response, and liver disease. Gastroenterology. 2011;140(4):1334-44.

93. Hickey RD, Mao SA, Glorioso J, Elgilani F, Amiot B, Chen H, Rinaldo P, Marler $R$, Jiang $H$, DeGrado TR, et al. Curative ex vivo liver-directed gene therapy in a pig model of hereditary tyrosinemia type 1. Sci Transl Med. 2016;8(349): 349 ra399.

94. Cosgrove BD, Cheng C, Pritchard JR, Stolz DB, Lauffenburger DA, Griffith LG. An inducible autocrine cascade regulates rat hepatocyte proliferation and apoptosis responses to tumor necrosis factor-alpha. Hepatology. 2008;48(1): 276-88

95. Cho $\mathrm{CH}$, Berthiaume $\mathrm{F}$, Tilles $\mathrm{AW}$, Yarmush ML. A new technique for primary hepatocyte expansion in vitro. Biotechnol Bioeng. 2008;101(2):345-56.

96. Shan J, Schwartz RE, Ross NT, Logan DJ, Thomas D, Duncan SA, North TE, Goessling W, Carpenter AE, Bhatia SN. Identification of small molecules for human hepatocyte expansion and iPS differentiation. Nat Chem Biol. 2013; 9(8):514-20

97. Levy G, Bomze D, Heinz S, Ramachandran SD, Noerenberg A, Cohen M, Shibolet O, Sklan E, Braspenning J, Nahmias Y. Long-term culture and expansion of primary human hepatocytes. Nat Biotechnol. 2015;33(12):1264-71.

98. Ramboer E, De Craene B, De Kock J, Vanhaecke T, Berx G, Rogiers V, Vinken M. Strategies for immortalization of primary hepatocytes. J Hepatol. 2014; 61(4):925-43.

99. Fox IJ, Chowdhury NR, Gupta S, Kondapalli R, Schilsky ML, Stockert RJ, Chowdhury JR. Conditional immortalization of Gunn rat hepatocytes: an ex vivo model for evaluating methods for bilirubin-UDPglucuronosyltransferase gene transfer. Hepatology. 1995;21(3):837-46.

100. Kawashita Y, Guha C, Moitra R, Wang X, Fox IJ, Roy-Chowdhury J, RoyChowdhury N. Hepatic repopulation with stably transduced conditionally immortalized hepatocytes in the Gunn rat. J Hepatol. 2008;49(1):99-106.

101. Ramackers W, Klose J, Vondran FW, Schrem H, Kaltenborn A, Klempnauer J, Kleine M. Species-specific regulation of fibrinogen synthesis with implications for porcine hepatocyte xenotransplantation. Xenotransplantation. 2014;21(5):444-53. 
102. Hara H, Gridelli B, Lin YJ, Marcos A, Cooper DK. Liver xenografts for the treatment of acute liver failure: clinical and experimental experience and remaining immunologic barriers. Liver Transpl. 2008;14(4):425-34.

103. Fitzpatrick E, Mitry RR, Dhawan A. Human hepatocyte transplantation: state of the art. J Intern Med. 2009;266(4):339-57.

104. Dabeva MD, Petkov PM, Sandhu J, Oren R, Laconi E, Hurston E, Shafritz DA Proliferation and differentiation of fetal liver epithelial progenitor cells after transplantation into adult rat liver. Am J Pathol. 2000;156(6):2017-31.

105. Libbrecht L, Roskams T. Hepatic progenitor cells in human liver diseases. Semin Cell Dev Biol. 2002;13(6):389-96.

106. Sackett SD, Li Z, Hurtt R, Gao Y, Wells RG, Brondell K, Kaestner KH, Greenbaum LE. Foxl1 is a marker of bipotential hepatic progenitor cells in mice. Hepatology. 2009;49(3):920-9.

107. Furuyama K, Kawaguchi Y, Akiyama H, Horiguchi M, Kodama S, Kuhara T, Hosokawa S, Elbahrawy A, Soeda T, Koizumi M, et al. Continuous cell supply from a Sox9-expressing progenitor zone in adult liver, exocrine pancreas and intestine. Nat Genet. 2011:43(1):34-41.

108. Reid LM. Stem/progenitor cells and reprogramming (plasticity) mechanisms in liver, biliary tree, and pancreas. Hepatology. 2016;64(1):4-7.

109. Briggs R, King TJ. Transplantation of Living Nuclei From Blastula Cells into Enucleated Frogs' Eggs. Proc Natl Acad Sci U S A. 1952;38(5):455-63.

110. Gurdon JB. The transplantation of living cell nuclei. Adv Morphog. 1964;4:1-43.

111. Ashworth D, Bishop M, Campbell K, Colman A, Kind A, Schnieke A, Blott S, Griffin H, Haley C, McWhir J, et al. DNA microsatellite analysis of Dolly. Nature. 1998;394(6691):329.

112. Evans MJ, Kaufman MH. Establishment in culture of pluripotential cells from mouse embryos. Nature. 1981;292(5819):154-6.

113. Martin GR. Isolation of a pluripotent cell line from early mouse embryos cultured in medium conditioned by teratocarcinoma stem cells. Proc Natl Acad Sci U S A. 1981;78(12):7634-8.

114. Thomson JA, Itskovitz-Eldor J, Shapiro SS, Waknitz MA, Swiergiel JJ, Marshall VS, Jones JM. Embryonic stem cell lines derived from human blastocysts. Science. 1998;282(5391):1145-7

115. Huang P, He Z, Ji S, Sun H, Xiang D, Liu C, Hu Y, Wang X, Hui L. Induction of functional hepatocyte-like cells from mouse fibroblasts by defined factors. Nature. 2011:475(7356):386-9.

116. Cowan CA, Atienza J, Melton DA, Eggan K. Nuclear reprogramming of somatic cells after fusion with human embryonic stem cells. Science. 2005; 309(5739):1369-73.

117. Takahashi K, Yamanaka S. Induction of pluripotent stem cells from mouse embryonic and adult fibroblast cultures by defined factors. Cell. 2006;126(4):663-76.

118. Takahashi K, Tanabe K, Ohnuki M, Narita M, Ichisaka T, Tomoda K, Yamanaka S. Induction of pluripotent stem cells from adult human fibroblasts by defined factors. Cell. 2007;131(5):861-72.

119. Zaret KS. Regulatory phases of early liver development: paradigms of organogenesis. Nat Rev Genet. 2002;3(7):499-512.

120. Hamazaki T, liboshi Y, Oka M, Papst PJ, Meacham AM, Zon LI, Terada N. Hepatic maturation in differentiating embryonic stem cells in vitro. FEBS Lett. 2001;497(1):15-9.

121. Novik El, Maguire TJ, Orlova K, Schloss RS, Yarmush ML. Embryoid bodymediated differentiation of mouse embryonic stem cells along a hepatocyte lineage: insights from gene expression profiles. Tissue Eng. 2006;12(6):1515-25.

122. Maguire T, Novik E, Schloss R, Yarmush M. Alginate-PLL microencapsulation: effect on the differentiation of embryonic stem cells into hepatocytes. Biotechnol Bioeng. 2006:93(3):581-91.

123. Gouon-Evans V, Boussemart L, Gadue P, Nierhoff D, Koehler Cl, Kubo A, Shafritz DA, Keller G. BMP-4 is required for hepatic specification of mouse embryonic stem cell-derived definitive endoderm. Nat Biotechnol. 2006;24(11):1402-11.

124. Soto-Gutierrez A, Kobayashi N, Rivas-Carrillo JD, Navarro-Alvarez N, Zhao D, Okitsu T, Noguchi H, Basma H, Tabata Y, Chen Y, et al. Reversal of mouse hepatic failure using an implanted liver-assist device containing ES cellderived hepatocytes. Nat Biotechnol. 2006;24(11):1412-9.

125. Cho CH, Parashurama N, Park EY, Suganuma K, Nahmias Y, Park J, Tilles AW, Berthiaume F, Yarmush ML. Homogeneous differentiation of hepatocyte-like cells from embryonic stem cells: applications for the treatment of liver failure. FASEB J. 2008;22(3):898-909

126. Kubo A, Shinozaki K, Shannon JM, Kouskoff V, Kennedy M, Woo S, Fehling $\mathrm{HJ}$, Keller G. Development of definitive endoderm from embryonic stem cells in culture. Development. 2004;131(7):1651-62.

127. Yasunaga M, Tada S, Torikai-Nishikawa S, Nakano Y, Okada M, Jakt LM, Nishikawa S, Chiba T, Era T, Nishikawa S. Induction and monitoring of definitive and visceral endoderm differentiation of mouse ES cells. Nat Biotechnol. 2005:23(12):1542-50.

128. Parashurama N, Nahmias $Y$, Cho $\mathrm{CH}$, van Poll D, Tilles AW, Berthiaume F, Yarmush ML. Activin alters the kinetics of endoderm induction in embryonic stem cells cultured on collagen gels. Stem Cells. 2008;26(2):474-84.

129. D'Amour KA, Agulnick AD, Eliazer S, Kelly OG, Kroon E, Baetge EE. Efficient differentiation of human embryonic stem cells to definitive endoderm. Nat Biotechnol. 2005;23(12):1534-41.

130. Si-Tayeb K, Noto FK, Nagaoka M, Li J, Battle MA, Duris C, North PE, Dalton S, Duncan SA. Highly efficient generation of human hepatocyte-like cells from induced pluripotent stem cells. Hepatology. 2010;51(1):297-305.

131. Zhu S, Rezvani M, Harbell J, Mattis AN, Wolfe AR, Benet LZ, Willenbring H, Ding S. Mouse liver repopulation with hepatocytes generated from human fibroblasts. Nature. 2014;508(7494):93-7.

132. Sekiya S, Suzuki A. Direct conversion of mouse fibroblasts to hepatocyte-like cells by defined factors. Nature. 2011;475(7356):390-3.

133. Ng S, Schwartz RE, March S, Galstian A, Gural N, Shan J, Prabhu M, Mota MM Bhatia SN. Human iPSC-derived hepatocyte-like cells support Plasmodium liverstage infection in vitro. Stem Cell Reports. 2015;4(3):348-59.

134. Raschi E, De Ponti F. Drug-induced liver injury: Towards early prediction and risk stratification. World J Hepatol. 2017:9(1):30-7.

135. Onakpoya IJ, Heneghan CJ, Aronson JK. Worldwide withdrawal of medicinal products because of adverse drug reactions: a systematic review and analysis. Crit Rev Toxicol. 2016;46(6):477-89.

136. Bale SS, Vernetti L, Senutovitch $N$, Jindal R, Hegde M, Gough A, McCarty WJ, Bakan A, Bhushan A, Shun TY, et al. In vitro platforms for evaluating liver toxicity. Exp Biol Med (Maywood). 2014;239(9):1180-91.

137. Maguire TJ, Novik E, Chao P, Barminko J, Nahmias Y, Yarmush ML, Cheng KC Design and application of microfluidic systems for in vitro pharmacokinetic evaluation of drug candidates. Curr Drug Metab. 2009;10(10):1192-9.

138. Lee PJ, Hung PJ, Lee LP. An artificial liver sinusoid with a microfluidic endothelial-like barrier for primary hepatocyte culture. Biotechnol Bioeng. 2007;97(5):1340-6.

139. Zhang MY, Lee PJ, Hung PJ, Johnson T, Lee LP, Mofrad MRK. Microfluidic environment for high density hepatocyte culture. Biomed Microdevices. 2008:10(1):117-21.

140. Novik E, Maguire TJ, Chao P, Cheng KC, Yarmush ML. A microfluidic hepatic coculture platform for cell-based drug metabolism studies. Biochem Pharmacol. 2010;79(7):1036-44.

141. Huh D, Hamilton GA, Ingber DE. From 3D cell culture to organs-on-chips. Trends Cell Biol. 2011;21(12):745-54.

142. Parent R, Marion MJ, Furio L, Trepo C, Petit MA. Origin and characterization of a human bipotent liver progenitor cell line. Gastroenterology. 2004; 126(4):1147-56

143. Parent R, Durantel D, Lahlali T, Salle A, Plissonnier ML, DaCosta D, Lesca G, Zoulim F, Marion MJ, Bartosch B. An immortalized human liver endothelia sinusoidal cell line for the study of the pathobiology of the liver endothelium. Biochem Biophys Res Commun. 2014;450(1):7-12.

144. Tilles AW, Baskaran $H$, Roy P, Yarmush ML, Toner M. Effects of oxygenation and flow on the viability and function of rat hepatocytes cocultured in a microchannel flat-plate bioreactor. Biotechnol Bioeng. 2001;73(5):379-89.

145. Du Y, Li N, Yang H, Luo C, Gong Y, Tong C, Gao Y, Lu S, Long M. Mimicking liver sinusoidal structures and functions using a 3D-configured microfluidic chip. Lab Chip. 2017:17(5):782-94.

146. Bodnar E, Olsen EG, Florio R, Dobrin J. Damage of porcine aortic valve tissue caused by the surfactant sodiumdodecylsulphate. Thorac Cardiovasc Surg. 1986;34(2):82-5.

147. Ott HC, Matthiesen TS, Goh SK, Black LD, Kren SM, Netoff TI, Taylor DA. Perfusion-decellularized matrix: using nature's platform to engineer a bioartificial heart. Nat Med. 2008;14(2):213-21.

148. Uygun BE, Soto-Gutierrez A, Yagi H, Izamis ML, Guzzardi MA, Shulman C, Milwid J, Kobayashi N, Tilles A, Berthiaume F, et al. Organ reengineering through development of a transplantable recellularized liver graft using decellularized liver matrix. Nat Med. 2010;16(7):814-20.

149. Soto-Gutierrez A, Zhang L, Medberry C, Fukumitsu K, Faulk D, Jiang H, Reing J, Gramignoli R, Komori J, Ross M, et al. A whole-organ regenerative medicine approach for liver replacement. Tissue Eng Part C Methods. 2011;17(6):677-86.

150. Ren H, Shi X, Tao L, Xiao J, Han B, Zhang Y, Yuan X, Ding Y. Evaluation of two decellularization methods in the development of a whole-organ decellularized rat liver scaffold. Liver Int. 2013;33(3):448-58. 
151. Shupe T, Williams M, Brown A, Willenberg B, Petersen BE. Method for the decellularization of intact rat liver. Organ. 2010;6(2):134-6.

152. Wu Q, Bao J, Zhou YJ, Wang YJ, Du ZG, Shi YJ, Li L, Bu H. Optimizing perfusion-decellularization methods of porcine livers for clinical-scale wholeorgan bioengineering. Biomed Res Int. 2015;2015:785474.

153. Marecki H, Bozorgzadeh A, Porte RJ, Leuvenink HG, Uygun K, Martins PN. Liver ex situ machine perfusion preservation: A review of the methodology and results of large animal studies and clinical trials. Liver Transpl. 2017; 23(5):679-95.

154. St Peter SD, Imber CJ, Kay J, James T, Friend PJ. Hepatic control of perfusate homeostasis during normothermic extrocorporeal preservation. Transplant Proc. 2003;35(4):1587-90

155. Moers C, Smits JM, Maathuis MH, Treckmann J, van Gelder F, Napieralski BP, van Kasterop-Kutz M, van der Heide JJ, Squifflet JP, van Heurn E, et al. Machine perfusion or cold storage in deceased-donor kidney transplantation. N Engl J Med. 2009;360(1):7-19.

156. Verstegen MMA, Willemse J, van den Hoek S, Kremers GJ, Luider TM, van Huizen NA, Willemssen F, Metselaar HJ, JNM IJ, van der Laan LWW et al: Decellularization of Whole Human Liver Grafts Using Controlled Perfusion for Transplantable Organ Bioscaffolds. Stem Cells Dev 2017;26(18):1304-15.

157. Stravitz RT, Kramer DJ. Management of acute liver failure. Nat Rev Gastroenterol Hepatol. 2009:6(9):542-53.

158. Glorioso JM, Mao SA, Rodysill B, Mounajjed T, Kremers WK, Elgilani F, Hickey $\mathrm{RD}$, Haugaa $\mathrm{H}$, Rose CF, Amiot B, et al. Pivotal preclinical trial of the spheroid reservoir bioartificial liver. J Hepatol. 2015;63(2):388-98.

159. Takebe T, Sekine K, Enomura M, Koike H, Kimura M, Ogaeri T, Zhang R-R, Ueno $\mathrm{Y}$, Zheng $\mathrm{Y}-\mathrm{W}$, Koike $\mathrm{N}$, et al. Vascularized and functional human liver from an iPSC-derived organ bud transplant. Nature. 2013;499(7459):481-4.

160. Avior Y, Levy G, Zimerman M, Kitsberg D, Schwartz R, Sadeh R, Moussaieff A, Cohen M, Itskovitz-Eldor J, Nahmias Y. Microbial-derived lithocholic acid and vitamin K2 drive the metabolic maturation of pluripotent stem cells-derived and fetal hepatocytes. Hepatology. 2015;62(1):265-78.

\section{Submit your next manuscript to BioMed Central and we will help you at every step:}

- We accept pre-submission inquiries

- Our selector tool helps you to find the most relevant journal

- We provide round the clock customer support

- Convenient online submission

- Thorough peer review

- Inclusion in PubMed and all major indexing services

- Maximum visibility for your research

Submit your manuscript at www.biomedcentral.com/submit 